\title{
South African and American sales managers: a comparative study
}

\author{
Brian van der Westhuizen \\ Department of Marketing/BA\&E, Califomia State University, P.0. Box 1280, Northridge, CA 91328-1280 \\ United States of America
}

Received January 1992, accepled January 1993

\begin{abstract}
The relatively unique socio-political and economic environment in South Africa frequently leads to the assertion that South African managers are very different when compared to their overseas counterparts. As far as could be ascertained, no studies have been conducted to test this presumption in the sales management area. In a recent study of two randomly selected groups of sales managers, one in South Africa and the other in the USA, it was established that there was substantial similarity between the two groups with respect to a number of areas of managerial behaviour.
\end{abstract}

Op grond van die relatief unieke sosiopolitiese en ekonomiese opset in Suid-Afrika, word die aanname dikwels gemaak dat Suid-Afrikaanse bestuurders baie van hulle ewekniek oorsee verskil. Sover vasgestel kan word, is nog geen studies onderneem om hierdie siening in die verkoopbestuursomgewing te toets nie. In ' $n$ onlangse studie, warrby twee geselekteerde groepe verkoopsbestuurders - in Suid-Afrikaanse groep en 'n groep van die VSA - op 'n toevallige basis betrek is, is vasgestel dat daar wel groot ooreenkomste ten opsigte van 'n hele aantal bestuursgedragskenmerke is.

\section{Introduction}

Sales managers have the very important task of ensuring that their firms' marketing strategy is effectively implemented at the operational level. The sales force is a very costly marketing resource that requires skillful management. According to research conducted in South Africa, personal selling dominates the promotion mix in all five principal product sectors, i.e., fast moving consumer goods; consumer durables; services; capital goods and industrial goods (Abratt \& Van der Westhuizen, 1985). Due to the relatively sophisticated level of development of the American market, it is reasonable to assume that sales management practice in that country could be used as a model for South African sales managers to follow. In order to establish whether or not there was any similarity between South African and American sales managers, a research study was conducted in the two countries.

\section{Problem definition}

The role and task of the sales manager is indeed a multifaceted one, and it would be difficult to obtain consensus on the variables that combine to influence the behaviour of sales managers. It was therefore decided to investigate four independent variables which were thought to significantly affect the behaviour (and hence influence the effectiveness) of sales managers. In addition, a very important outcome of sales management behaviour, namely sales force productivity, was also measured and compared. The four independent variables chosen were: corporate ethical values; organizational commitment, management decision style, and Machiavellianism.

Interest in business ethics in general has risen dramatically since the early 1980 s and much concern for the subject has been shown by corporate managers (Cooke, 1986). As much as there has been a concern about business ethics in general, considerable attention has been given to ethics in marketing. Indeed, Laczniak \& Murphy (1985) claimed that marketing was the functional area of business most closely related to the abuse of ethics. Corporate ethical values were defined by Hunt, Wood \& Chonko (1989) as: '... a composite of the individual ethical values of managers and both the formal and informal policies on ethics of the organization.'

Numerous scholarly works suggest that organizational commitment is positively associated with organizational performance (e.g., Buchanan, 1974; Mowday \& McDade, 1979). No doubt contributing to the interest in the relationship between organizational commitment and productivity is the apparent ability of the Japanese to maintain a highly committed workforce (Lincoln \& Kalleberg, 1985). One of the common conclusions drawn from this observation is that Japanese workers are more committed to the organizations they work for than their American counterparts and this explains the greater productivity of the Japanese workforce (Luthans, McCaul \& Dodd, 1985). There are many other manifestations of the assumption that the more organizational commitment the better (e.g., Bateman \& Strasser, 1984; Logan, 1984). Organizational commitment was defined by Hunt, Chonko \& Wood (1985) as: '... a strong desire to remain a member of the particular organization, given opportunities to change jobs.'

One of a manager's key functions is decision making. In the narrow sense, managerial decision making can be defined as making a choice between two or more alternative courses of action. More broadly, decision making can be said to include all the actions necessary before a final choice is made. Many of these actions will be managerial in nature, for example situation analysis, which was probably the reason Simon (1965) suggested that it might be as well to treat: '... decision-making as synonymous with managing'. Hence it can be inferred that management style and management decision style are synonymous. While there has been much written about management and management style, not many empirical studies on the topic have been conducted (Van der Westhuizen, 1991). A study was undertaken by Slater (1989) to test the universal and contingency theories relating managerial style to performance and to test the importance of the relationships among the three components of: (i) managerial style (personality traits, background 
characteristics and managerial behaviours); (ii) business unit strategy; and (iii) business unit performance. The results provided support for the theory that some managerial style characteristics are universally desirable and for the complementary theory that the importance of others is contingent upon the strategy of the business unit. He also found that representatives from all three categories of managerial style were found to be related to business unit performance. In other words, no particular style was found to produce superior performance compared to others.

Many present-day studies of business issues such as leadership and success are based on early writings. One such notable work is that of Niccold Machiavelli, a Florentine nobleman who held numerous diplomatic appointments in the late fifteenth and early sixteenth centuries, before turning to writing. His best known work, 'The Prince,' was published in 1513 and essentially he concluded that success or failure of states depended directly on the qualities of the leader. His work inspired a number of researchers to investigate his theories and the concept of Machiavellianism was evolved. An important development was a scale to measure Machiavellianism, known as the Mach IV Scale, by Christie and Geis (1970). The twentieth century Machiavellian is defined by Calhoon as:

'... one who employs aggressive, manipulative, exploiting, and devious moves in order to achieve personal and organizational objectives' (1969).

Sales force productivity has interested researchers in the marketing discipline for some considerable time, one of the earliest recorded mentions of the topic being that of Hoyt (1913). Much empirical research aimed at identifying explanatory variables related to the performance of salespeople has been carried out over the past eight decades. Yet, as concluded in extensive reviews of empirical research, the cumulative results of all this research indicate that unequivocal predictors of sales force productivity have not yet been identified (Churchill et al., 1985; Szymanski, 1988). The need to address this issue is hardly open to dispute. A report in the December 1988 edition of Sales \& Marketing Management analyzed the productivity results in 19 key industries in the USA over the ten year period 1977-1987 and found that the average real compound annual growth rate was $-0.9 \%$ with selling costs having increased almost twice as fast as average sales volume per salesperson (O'Connell, 1988). There do not appear to have been any similar studies undertaken in South Africa, but given the fact of double-digit inflation since 1974, the situation might be much worse than in the USA.

Having regard to the factors discussed above, five null hypotheses were developed and then tested. The hypotheses are:

$\mathrm{H}_{0} 1$ There is no difference between the perception of the corporate ethical values of their employer organizations by South African and American sales managers.

$\mathrm{H}_{0} 2$ There is no difference between the degree of organizational commitment indicated by South African and American sales managers.

$\mathrm{H}_{0} 3$ There is no difference between the management decision styles of South African and American sales managers.
$\mathrm{H}_{0} 4$ There is no difference between the level of Machiavellianism indicated by South African and American sales managers.

$\mathrm{H}_{0} 5$ There is no difference between the sales force productivity scores reported by South African and American sales managers.

\section{Research methodology}

\section{Samples}

Having specified the objectives of this research study and developed appropriate hypotheses to be tested, two survey populations were selected - one in South Africa and one in the United States of America. Appropriate sample frames were identified and samples specified.

The South African sample frame used was the latest corporate member list of the Institute of Marketing Management. Service industries were excluded and 264 randomly selected sales managers in manufacturing and distribution firms were targeted, of whom 87 responded.

The American sample frame used was the latest list of manufacturing and distribution firms registered with the career centre of a prominent Southern California university as potential employers of graduates, and 245 randomly selected sales managers were targeted, of whom 81 responded.

As can be seen in Table 1, there was fairly good correspondence between the two samples.

\section{Questionnaire and research instruments}

The questionnaire used comprised five different research instruments, although the first two were combined in Section One of the questionnaire. These two instruments were developed by Hunt, Wood \& Chonko (1989) and Hunt, Chonko \& Wood (1985). The first instrument, consisting of five statements, dealt with corporate ethical values. This measure incorporated three broad-based perceptions:

- The extent to which employees perceive that managers are acting ethically in their organization.

- The extent to which employees perceive that managers are concerned about ethical issues in their organization.

- The extent to which employees perceive that ethical behaviour is rewarded or that unethical behaviour is punished in their organization.

The five statements Hunt, Wood \& Chonko (1989) developed were:

1. Managers in my company often engage in behaviours that I consider to be unethical (coded ETH1 in Table 2).

Table 1 Comparison of samples by principal activity

\begin{tabular}{lcccc}
\hline Principal & \multicolumn{2}{c}{ SA sample } & \multicolumn{2}{c}{ USA sample } \\
activity & $n$ & $\%$ & $n$ & $\%$ \\
\hline Manufacturing & 43 & 49.43 & 38 & 46.91 \\
Distribution & 44 & 50.57 & 43 & 53.09 \\
\hline Totals & 87 & 100.00 & 81 & 100.00 \\
\hline
\end{tabular}


2. In order to succeed in my company, it is often necessary to compromise one's ethics (coded ETH2 in Table 2).

3. Top management in my company has let it be known in no uncertain terms that unethical behaviours will not be tolerated (coded ETH3 in Table 2).

4. If a manager in my company is discovered to have engaged in unethical behaviour that results primarily in personal gain (rather than corporate gain), he or she will be promptly reprimanded (coded ETH4 in Table 2).

5. If a manager in my company is discovered to have engaged in unethical behaviour that results primarily in corporate gain (rather than personal gain), he or she will be promptly reprimanded (coded ETH5 in Table 2).

(Note that, due to the wording, statements 1 and 2 are reverse scored.)

Respondents were asked to respond to each statement using a seven-point Likert format, where:

1 = Strongly disagree

2 = Generally disagree

3 = Moderately disagree

$4=$ Neither agree nor disagree

$5=$ Moderately agree

6 = Generally agree

7 = Strongly agree

The second instrument, consisting of four statements, dealt with organizational commitment. This measure incorporated the degree of loyalty marketers would have to an organization, given four attractive incentives to change companies. The four incentives are:

- Higher pay

- More creative freedom

- More job status

- Friendlier working environment

The four statements Hunt, Chonko \& Wood (1985) developed were:

1. I would be willing to change companies if the new job offered a $25 \%$ pay increase (coded OC1 in Table 3).

2. I would be willing to change companies if the new job offered more creative freedom (coded $\mathrm{OC} 2$ in Table 3).

3. I would be willing to change companies if the new job offered more status (coded OC3 in Table 3).

4. I would be willing to change companies if the new job was with people who were more friendly (coded OC4 in Table 3).

Respondents were asked to respond to each statement using the same seven-point Likert format detailed above.

The third instrument used was the Mach IV scale developed by Christie \& Geis (1970). It consists of twenty statements and was scored according to the method established by Christie \& Geis. This involves adding a constant of 20 to all scores in order that the total score be at the neutral point of 100 . Theoretically, this implies a median rating of four on all 20 statements plus the constant (four times 20 items plus 20). The minimum score is $\mathbf{4 0}$ (one times 20 items plus 20) and the maximum score is 160 (seven times 20 items plus 20).

The fourth instrument used was the Decision Styles Inventory (DSI) of Rowe, Mason \& Dickel (1987). The decision style model they developed is based on two dimensions - the manager's cognitive complexity and values orientation. It incorporates the task/people dimension as part of the values orientation and develops a distinction between the manager and the leader based on cognitive complexity. The right and left halves of the model correspond with the results of research on the right and left hemispheres of the brain. The four basic management decision styles were described as directive, analytic, conceptual and behavioural. (These are coded DIR, ANA, CON, and BEH respectively in Table 5.) The DSI consists of twenty statements with four alternative responses to each statement. Respondents are required to score each alternative response as follows:

$8=$ When the response is most like you.

$4=$ When the response is moderately like you.

2 = When the response is slightly like you.

1 = When the response is least like you.

The scores from each respondent are entered into the computer program developed by Rowe, Mason \& Dickel (1987) which then calculates the scores on each dimension and prints out a summary of the individual's management decision style.

The fifth instrument used was the Sales Force Productivity Score (SFPS), specifically developed for this research study. The approach taken was to construct a multi-aturibute linear compensatory instrument combining the input and output factors considered important to the achievement of sales force productivity, in a modified version of the general productivity equation. It was decided to use the weighted sum of the input and output factors as the numerator and the weights only in the denominator as a normalizing factor. Therefore, the instrument developed is basically a normalized weighted sum of inputs and outputs.

A number of multi-aturibute approaches have been developed by researchers, all of them being offshoots of the model formulated by Fishbein in the 1960s. Originally applied to consumer research, Fishbein's model suggests that an attitude toward something is a function of the strength of belief about it and what Fishbein called: '... the evaluative aspect of those beliefs' (Fishbein, 1967: 394). In straightforward terms one would call the 'strength of belief the weight and the 'evaluative aspect of the belief' the score.

Algebraically, this may be expressed as follows:

$$
A_{0}=\sum_{i=1}^{n}\left(B_{i} \alpha_{i}\right)
$$

where:

$A_{0}=$ the attitude toward object 0

$B_{i}=$ the strength of belief (weight) $i$ about $o$

$a_{i}=$ the evaluative aspect of $B_{i}$ (score)

$n=$ the number of beliefs about 0

Since Fishbein's model became widely known in marketing, researchers have formulated alternative multi-auribute models to develop measures that are more specifically related to their needs. These models are typically compensatory in nature, that is, the weakness on one aturibute can be compensated for by the strength on another. The products of the individual scores and weights of each aturibute are then summed to determine the overall score. 
Tuming now to the development of the SFPS, a study of the relevant literature indicated that a fairly substantial number of input and ouput factors appeared to be considered important by various authors. It was difficult to establish any consensus on those considered most important. hence the decision was taken to limit the number of input and output factors to five each. The five were chosen on the basis of their presumed universal applicability to most sales organizations.

The five input factors chosen were:

- Sales call planning

- Time planning

- Prospecting

- Sales presentations

-Closing

The five output factors chosen were:

- Achievement of sales volume targets

- Achievement of profitability targets

- Achievement of market share targets

- Conversion rate (orders/calls)

- Customer satisfaction

Each of the five input and output factors were ascribed a weight (by the sales managers polled) from 1 to 5 where:

1 = Not at all important

2 = Not very important

3 = Quite important

4 = Very important

5 = Extremely important

Next, the sales managers were asked to score the performance of their sales forces on each of the five input and outpul factors from 1 to 5 where:

1 = Unacceptable

2 = Below average

3 = Average

4 = Above average

5 = Outstanding

Once having weighted and scored each factor, the SFPS can be computed, using the formula developed for the instrument, which is:

$$
\text { SFPS }=\frac{\sum_{i=1}^{n=10}\left(a_{i} b_{i}\right)}{\sum_{i=1}^{n=10}\left(b_{i}\right)}
$$

where:

SFPS = Sales Fonce Productivity Score

$a_{i} \quad=$ The score of factor $i$

$b_{i}=$ The weight of factor $i$

$n \quad=$ The number of factors

It will be apparent that the equation is easily adaptable to any number of factors. This is one of the inherent advantages of SFPS, since it offers the individual sales manager the flexibility of being able to choose the particular factors be or she deems applicable in a given situation.

\section{Data collection}

The primary data was collected by means of a mailed ques. tionnaire which incorporated the five research instruments described above. The only incentive offered was a copy of the respondent's management decision style printout. The number of usable questionnaires returned by the South African sales managers was 87 , a response rate of $32.95 \%$. The number of usable questionnaires returned by the American sales managers was 81 , a response rate of $33.06 \%$. Given the length and relative complexity of the questionnaire (it was eight pages long and required response to 69 statements or items), the response received is considered very good if compared to the response obtained for similar research studies. In an industrial mail survey done in 1988, the highest response obtained was $24.07 \%$ when a financial reward was offered for responding (London \& Dommeyr, 1990).

\section{Data processing}

The primary data was processed using SPSS Release 4.0 o perform the multiple regression procedures and the paired t-tests. The objective was to look for any significant differences between the South African and American samples on the variables measured.

\section{Research findings}

The values obtained from the first statistical analysis, w establish the differences between the mean scores of the independent and dependent variables, are summarized in Tables 2 to 6.

It will be noted that there were significant differences be tween the means of only the first two ethical value items. This suggests that the American sales managers generally agreed that managers in their companies often engaged in behaviours that they considered to be unethical and were personally prepared to compromise their ethics in order to succeed in their companies. The South African sales managers, on the other hand, only moderately agreed on the same two points. The inference, therefore, is that the Amencan sales managers perceived that managers in their organizations were slightly less ethical than managers in the South African sales managers' organizations.

Table 2 Differences in mean scores for ethical values

\begin{tabular}{lccccccccc}
\hline $\begin{array}{l}\text { Vari- } \\
\text { able }\end{array}$ & \multicolumn{3}{c}{ SA sample } & \multicolumn{4}{c}{ USA sample } & i & 2-uil \\
& $n$ & Mean & S.D. & $n$ & Mean & S.D. & value & prob. \\
\hline ETH1 & 87 & 5.471 & 1.810 & 81 & 6.025 & 1.369 & -2.22 & $0.028 *$ \\
ETH2 & 87 & 5.759 & 1.562 & 81 & 6.148 & 1.295 & -1.75 & $0.082 *$ \\
ETH3 & 87 & 5.965 & 1.551 & 81 & 6.136 & 1.339 & -0.76 & 0.449 \\
ETH4 & 87 & 6.414 & 1.427 & 81 & 6.370 & 1.167 & 0.22 & 0.830 \\
ETHS & 87 & 5.230 & 1.891 & 81 & 5.605 & 1.678 & -1.177 & \\
\hline
\end{tabular}

* $p<0.05$

$* * p<0.10$

(ETH 1, ETH2, ETH3, ETH4, and ETH5 are the five statements of the to search instrument used.) 
There was no significant difference between the third ethical values statement, both samples generally agreeing that top management in their companies has let it be known in no uncertain terms that unethical behaviour will not be wolerated. What appears to be of particular note is that, in both samples, the highest mean score was for ETH4 which concerned personal gain. (There was no significant difference between the two samples.) This would seem to suggest that the employer organizations take a very strong position on unethical behaviour on the part of employees. Conversely, however, the lowest mean score for both samples was for ETH5 which concemed corporate gain. (Again, there was no significant difference between the two samples.) This would seem to suggest that employer organizations are somewhat less concerned about unethical behaviour which results in corporate gain. One is led to observe that this is a rather unfortunate state of affairs (see Table 3).

Table 3 Differences in mean scores for organizational commitment

\begin{tabular}{|c|c|c|c|c|c|c|c|c|}
\hline \multirow{2}{*}{$\begin{array}{l}\text { Vari- } \\
\text { able }\end{array}$} & \multicolumn{3}{|c|}{ SA sample } & \multicolumn{3}{|c|}{ USA sample } & \multirow{2}{*}{$\begin{array}{c}t \\
\text { value }\end{array}$} & \multirow{2}{*}{$\begin{array}{l}\text { 2-tail } \\
\text { prob. }\end{array}$} \\
\hline & $n$ & Mean & S.D. & $n$ & Mean & S.D. & & \\
\hline $\mathrm{OCl}$ & 87 & 3.782 & 1.845 & 81 & 4.420 & 1.877 & -2.22 & $0.028 *$ \\
\hline$O C 2$ & 87 & 4.103 & 1.971 & 81 & 4.123 & 1.887 & -0.07 & 0.947 \\
\hline OC3 & 87 & 3.402 & 1.852 & 81 & 3.653 & 1.726 & -0.91 & 0.364 \\
\hline OC4 & 87 & 3.069 & 1.879 & 81 & 3.049 & 1.635 & 0.07 & 0.943 \\
\hline
\end{tabular}

$* p<0.05$

$(O C 1, O C 2, O C 3$, and $O C 4$ are the four statements of the research instrument used.)

It will be noted that there was a significant difference between the means of only the first organizational commitment item. This suggests that the American sales managers indicated somewhat more willingness to change companies than the South African sales managers if the new job offered a $25 \%$ pay increase. Perhaps the reason for this is the perception on the part of the American sales managers that a $25 \%$ increase would represent a substantial real increase, given the much lower rate of inflation and personal income tax in America compared to South Africa.

Both groups were neutral to the second statement regarding their willingness to change companies if the new job offered more creative freedom and there was no significant difference between the mean scores of the two groups. Presumably this means that they do not value creative freedom that highly.

Both groups tended to moderately disagree that they would be willing to change companies if the new job offered more status. Similarly, both groups were virtually equal in scoring 'moderately disagree' to the proposition that they would be willing to change jobs if they could work with people who were more friendly. In both cases there was no significant difference between the mean scores of both groups. Presumably this means that they are unconcerned about status or the friendliness of their co-workers (see Table 4).
Table 4 Differences in mean scores for Machiavellianism

\begin{tabular}{|c|c|c|c|c|c|c|c|c|}
\hline \multirow{2}{*}{$\begin{array}{l}\text { Vari- } \\
\text { able }\end{array}$} & \multicolumn{3}{|c|}{ SA sample } & \multicolumn{3}{|c|}{ USA sample } & \multirow{2}{*}{$\begin{array}{c}\text { t } \\
\text { value }\end{array}$} & \multirow{2}{*}{$\begin{array}{l}\text { 2-tuil } \\
\text { prob. }\end{array}$} \\
\hline & $n$ & Mean & S.D. $n$ & & Mean & S.D. & & \\
\hline MAC & 87 & 99.41 & 10.00 & 81 & 101.1 & 8.361 & -1.21 & 0.226 \\
\hline
\end{tabular}

(MAC is the research instrument used - the MACH IV scale)

It will be noted that there was no significant difference between the means for the Machiavellianism score of both samples. This would suggest that there is no significant difference in the level of Machiavellianism indicated by both the South African and American sales managers polled in this study. What is of significance, however, is the high scores registered when compared to other research findings. The Mach IV scores registered by the South African and American sales managers are amongst the highest recorded in a variety of studies (Van der Westhuizen, 1991). Of particular interest is the study of Chonko (1982) of purchasing managers which produced a mean score of 99.6 which is fractionally higher than the mean score for the South African sales managers and just slightly less than the mean score of the American sales managers. Intuitively, one would expect purchasing managers and sales managers to be rather Machiavellian. The findings of this research study therefore tend to support intuitive judgement (see Table 5).

It will be noted that there were no significant differences between the means for the management decision styles of both samples (see Table 6).

It will be noted that there was no significant difference between the means for the sales force productivity scores for both samples. No specific inferences can be drawn from this finding, however, since much more development work on the SFPS instrument is needed in order to establish its validity and reliability.

Multiple regression procedures were performed to establish whether or not there was a relationship between any of the independent variables and the dependent variable, the sales force productivity score (SFPS). The values obtained are summarized in Tables $7 \mathrm{a}$ to $10 \mathrm{~d}$.

Shown in Tables $7 \mathrm{a}$ and $7 \mathrm{~b}$ are the results of the linear regression analysis with sales force productivity score as the

Table 5 Differences in mean scores for management decision styles

\begin{tabular}{llllllllll}
\hline $\begin{array}{l}\text { Vari- } \\
\text { able }\end{array}$ & \multicolumn{3}{c}{ SA sample } & \multicolumn{4}{c}{ USA sample } & $t$ & 2-tail \\
& $n$ & Mean & S.D. & $n$ & Mean & S.D. & value & prob. \\
\hline DIR & 87 & 81.70 & 14.83 & 81 & 80.30 & 12.41 & 0.66 & 0.508 \\
ANA & 87 & 83.83 & 13.95 & 81 & 85.96 & 14.97 & -0.96 & 0.340 \\
CON & 87 & 77.13 & 13.95 & 81 & 75.43 & 14.15 & 0.78 & 0.436 \\
BEH & 87 & 57.34 & 14.76 & 81 & 58.31 & 15.33 & -0.42 & 0.679 \\
\hline
\end{tabular}

(DIR = Directive; ANA = Analytic; CON = Conceptual; and BEH = Behavioural management decision styles.) 
Table 6 Differences in mean scores for sales force productivity scores

\begin{tabular}{llllllllll}
\hline $\begin{array}{l}\text { Vari- } \\
\text { able }\end{array}$ & $n$ & Mean & S.D. & $n$ & Mean & S.D. & value & prob. \\
\hline SFPS & 87 & 3.443 & 0.533 & 81 & 3.511 & 0.575 & -0.80 & 0.423 \\
\hline (SFPS = Sales Force Productivity Score.) & & & & & & & \\
\hline
\end{tabular}

Table 7a Ethical values \& sales force productivity score: estimated regression coefficients, $t$-test values \& coefficient of multiple determination - South African sample

\begin{tabular}{lccrl}
\hline Variable & Coeff. & St.error & t-value & Prob $(>t)$ \\
\hline Consunt & 3.747311 & 0.326075 & 11.492 & 0.0000 \\
ETH1 & 0.227918 & 0.044091 & 1.523 & 0.1316 \\
ETH2 & -0.040765 & 0.047985 & -0.290 & 0.7726 \\
ETH3 & -0.151464 & 0.040533 & -1.285 & 0.2026 \\
ETH4 & -0.205908 & 0.045964 & -1.674 & 0.0980 \\
ETH5 & 0.143776 & 0.036459 & 1.112 & 0.2693 \\
\hline
\end{tabular}

Table $7 \mathrm{~b}$ Analysis of variance for the full regression South African sample

\begin{tabular}{lrrrrc}
\hline Source & Sum sq. & Deg.free. & Mean sq. & F-ratio & Prob. > F \\
\hline Model & 2.56070 & 5 & 0.51214 & 1.89491 & 0.1042 \\
Error & 21.89194 & 81 & 0.27027 & - & - \\
\hline
\end{tabular}

$\mathbf{R}^{2}=0.10472 ;$ Adjusted $\mathbf{R}^{2}=0.04946$; Standand error of estimate = 0.51988

Table 7c Ethical values \& sales force productivity score: estimated regression coefficients, $t$-test values \& coefficient of multiple determination - American sample

\begin{tabular}{lllrl}
\hline Constant & Coeff. & Sterror & $t$-value & Prob. > 1 \\
\hline Constant & $\mathbf{3 . 6 8 7 6 5 9}$ & $\mathbf{0 . 4 9 6 4 9 9}$ & $\mathbf{7 . 4 2 7}$ & 0.0000 \\
ETH1 & $\mathbf{0 . 1 6 2 1 7 5}$ & $\mathbf{0 . 0 5 9 7 9 6}$ & 1.138 & 0.2586 \\
ETH2 & 0.015604 & 0.061295 & 0.113 & 0.9104 \\
ETH3 & -0.137052 & 0.055141 & -1.066 & 0.2896 \\
ETH4 & -0.096086 & 0.075554 & -0.626 & 0.5329 \\
ETH5 & 0.017245 & 0.059269 & 0.100 & 0.9209 \\
\hline
\end{tabular}

Table 7d Analysis of variance for the full regression American sample

\begin{tabular}{lccccc}
\hline Source & Sum sq. & Deg. free & Mean sq. & F-rntio & Prob. > F \\
\hline Model & 0.95850 & 5 & 0.19170 & 0.56467 & 0.7267 \\
Error & 25.46150 & 75 & 0.33949 & - & - \\
\hline$R^{2}=0.03628 ;$ & Adjusted $\mathbf{R}^{2}=-0.02797$; Standard error of estimnce = \\
0.58265 .
\end{tabular}

dependent variable and corporate ethical values as the in dependent variables for the South African sample. None of the $t$-values for the corporate ethical values items were significant. This finding suggests that there is no relationship between corporate ethical values and sales force pro. ductivity score in the South African sample. The analysis of variance (ANOVA) for the full regression is not significan either, with an overall F-ratio of 1.89491 at $p>0.1042$.

Shown in Tables $7 c$ and $7 d$ are the results of the liner multiple regression analysis with sales force productivity score as the dependent variable and corporate ethical values as the independent variables for the American sample. None

Table 8a Organizational commitment \& sales force productivity score: estimated regression coefficients, $T$-tesi values \& coefficient of multiple determination - South African sample

\begin{tabular}{lcccc}
\hline Variable & Coeff. & St.error & t-value & Prob. $>t$ \\
\hline Constant & 3.649536 & 0.147708 & 24.708 & 0.0000 \\
OC1 & -0.146201 & 0.038239 & -1.105 & 0.2725 \\
OC2 & -0.294515 & 0.041321 & -1.928 & 0.0573 \\
OC3 & 0.159484 & 0.043651 & 1.052 & 0.2959 \\
OC4 & 0.141765 & 0.042432 & 0.948 & 0.3458 \\
\hline
\end{tabular}

Table $8 b$ Analysis of variable for the full regression South African sample

\begin{tabular}{lrrrcc}
\hline Source & Sum sq. & Deg.free. & Mean sq. & F-ratio & Prob. > F \\
\hline Model & 1.70761 & 4 & 0.42690 & 1.53906 & 0.1966 \\
Error & 22.74503 & 82 & 0.27738 & - & - \\
\hline
\end{tabular}

$\mathbf{R}^{2}=0.06983$; Adjusted $\mathbf{R}^{2}=0.02446 ;$ Standard error of estimate $=$ 0.52667 .

Table 8c Organizational commitment \& sales force productivity score: estimated regression coefficients, $t$-test values \& coefficient of multiple determination American sample

\begin{tabular}{lllll}
\hline Variable & Coeff. & St.error & $t$-value & Prob. $>t$ \\
\hline Constant & 3.829804 & 0.190986 & 20.053 & 0.0000 \\
OC1 & -0.171891 & 0.039138 & -1.345 & 0.1826 \\
OC2 & -0.006753 & 0.050780 & -0.041 & 0.9678 \\
OC3 & -0.054227 & 0.058536 & -0.308 & 0.7586 \\
OC4 & -0.010806 & 0.051472 & -0.074 & 0.9414 \\
\hline
\end{tabular}

Table 8d Analysis of variance for the full regression American sample

\begin{tabular}{lrrccc}
\hline Source & Sum sq & Deg.free. & Mean sq. & F-ratio & Prob. > F \\
\hline Model & 1.13403 & 4 & 0.28351 & 0.85211 & 0.4967 \\
Error & 25.28597 & 76 & 0.33271 & - & - \\
\hline
\end{tabular}

$\mathbf{R}^{2}=0.04292 ;$ Adjusted $\mathbf{R}^{2}=-0.00745$; Standard error of estimate $=$ 0.57681 
of the $t$-values for the corporate ethical values items were significant. This finding suggests that there is no relationship between corporate ethical values and sales force productivity in the American sample. The analysis of variance (ANOVA) for the full regression is not significant either, with an overall F-ratio of 0.56467 at $p>0.7267$.

Shown in Tables $8 \mathrm{a}$ and $8 \mathrm{~b}$ are the results of the linear multiple regression analysis with sales force productivity score as the dependent variable and organizational commitment items as the independent variables for the South African sample. None of the $t$-values for the organizational commitment items were significant at the 0.05 level. However, only one item (COMMIT) was significant at the 0.10 level $(t=-1.928 ; \mathrm{p}>0.0573)$. This finding suggests that there is a negative relationship between this item and sales force productivity score for the South African sample. The analysis of variance (ANOVA) for the full regression, however, is not significant, with an overall F-ratio of 1.53906 at p $>0.1986$. It is therefore concluded that there is no significant relationship between organizational commitment and the sales force productivity score for the South African sample.

Shown in Tables $8 \mathrm{c}$ and $8 \mathrm{~d}$ are the results of the linear multiple regression analysis with sales force productivity score as the dependent variable and organizational commitment items as the independent variables for the American sample. None of the $t$-values for the organizational commitment items were significant. The analysis of variance (ANOVA) for the full regression is not significant either, with an overall F-ratio of 0.85211 at $p>0.4967$. This finding suggests that there is no significant relationship between organizational commitment and the sales force pruductivity score for the American sample.

Shown in Tables $9 \mathrm{a}$ and 96 are the results of the linear multiple regression analysis with sales force productivity score as the dependent variable and the four management decision styles as the independent variables for the South African sample. None of the t-values are significant. The analysis of variance (ANOVA) for the full regression is not significant either, with an overall F-ratio of 0.66711 at $p>$ 0.5746 . This finding suggests that there is no significant relationship between mangement decision styles and the sales force productivity score for the South African sample.

Shown in Tables $10 \mathrm{~h}$ and $10 \mathrm{~b}$ are the results of the linear multiple regression andysis with sales force productivity score as the dependent variable and Machiavellianism as the independem variable for the South African sumple. The it value is noc significan. The analysis of variance (ANOVA) for the full regression is not significant either, with an overall F-ratio of 0.37326 a $p>0.5429$. Thix finding suggests that there is no significant relationahip botween Machiavellianison and the coles force productivity neore for the South African cample.

In Tables $10 \mathrm{c}$ and $10 \mathrm{~d}$ the results are shown of the linear multiple regression anolysis with ole force productivity score as the depeadent variable and Machiavellianilill at the independent varable far the Americun sample. The 1 -valus is not significan. The anatysis of variance (ANUVA) thr the

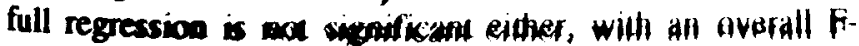
ratio of 0.25415 a $>0.6156$. This finding sithossti that
Table on Management decision styles a sales force productivity score: estimated regression coeficients, itest values \& coefficient of multiple determination South African sample

\begin{tabular}{lllcc}
\hline Variable & Coeff. & St. error & t.value & Prob. > t \\
\hline Constant & 2.427287 & 0.909207 & 2.670 & 0.0091 \\
DIR & 1.000000 & 0.000000 & - & - \\
ANA & 0.190930 & 0.005612 & 1.300 & 0.197 \\
CON & 0.035220 & 0.004753 & 0.283 & $0.7 m$ \\
BEH & 0.144766 & 0.0048 & 1.072 & 0.2468 \\
\hline
\end{tabular}

Table 9b Analysis of variance for the full regreseion South African sample

\begin{tabular}{lccccc}
\hline Source & Sum sq. & Deg. free. & Meen sq. & F-ratio & Prob > F \\
\hline Model & 0.57573 & 3 & 0.19191 & 0.66711 & 0.5746 \\
Error & 23.87691 & 83 & 0.28767 & - & - \\
\hline
\end{tabular}

$R^{2}=0.02354 ;$ Adjused $R^{2}=-0.01175 ;$ Sundurd error of eximene 0.53635 .

Table Sc Management decision styles \& sales lorce productivity score: estimated regression coefficinots, 1test values \& coefficient of multiple determination American sample

\begin{tabular}{|c|c|c|c|c|}
\hline Variable & Coeff. & St.error & Pralue & Prob $>1$ \\
\hline Constant & 4.647445 & $0.9 \mathrm{~m}_{13}$ & 4.753 & 0.0000 \\
\hline DIR & -0.025821 & 0.006444 & a.11s & 0.2533 \\
\hline ANA & 1.000000 & 0.000000 & - & - \\
\hline CON & .0 .283013 & 0.005212 & -2.205 & $0.0 \mathrm{~s}$ \\
\hline BEH & .0079387 & 0.004925 & .0604 & $0.5 \times 75$ \\
\hline
\end{tabular}

Table sd Analysis of varibale for the full regreseion American sample

\begin{tabular}{|c|c|c|c|c|c|}
\hline Source & Sum $\$$ & Denffine. & Maen aq. & $R_{\text {ravio }}$ & Prom $>F$ \\
\hline Moxtal & 1.00024 & 3 & 0.63475 & 1.99303 & 0.1219 \\
\hline finer & $24.515 \%$ & $m$ & 0.31839 & $=$ & - \\
\hline
\end{tabular}

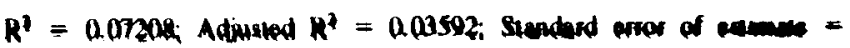
0.56426.

there is no significan placionship botwesn Mochiavellianism and the ales force productivity sogre for the Amoricese rample:

\section{Interaretation of the findiage}

The hypathasps dovelaped for this research sudy an mow

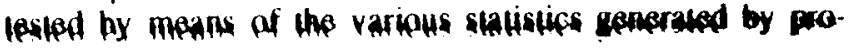
cessing the primary data collected.

Hal There is na difference between the parception of ung 